\title{
PERAN PEMERINTAH DAERAH DALAM PEMBERDAYAAN MASYARAKAT PETANI KAKAO DI DESA KAYUANGIN KECAMATAN MALUNDA KABUPATEN MAJENE
}

Darmansyah $^{1}$, Muhammad Yusuf Badjido ${ }^{2}$, Ahsan Samad ${ }^{1}$ ${ }^{1}$ Program Studi Ilmu Pemerintahan Fakultas Ilmu Sosial dan Ilmu Politik Universitas Muhammadiyah Makassar Jl Sultan Alauddin No 259 Makassar 90221 Telp. 0411-866972 ext. 107. Fax. 0411-8655888 darmansyah@yahoo.co.id \& ahsansamad@gmail.com 2Program Studi Ilmu Adminitrasi Negara Fakultas Ilmu Sosial dan Ilmu Politik Universitas Muhammadiyah Makassar Jl Sultan Alauddin No 259 Makassar 90221 Telp. 0411-866972 ext. 107. Fax. 0411-8655888 Yusufbadjido@gmail.com

\begin{abstract}
This study aims to determine the role of local government in empowering cocoa farmers in the village community Kayuangin Malunda District of Majene and determine the factors that influence the local government's role in empowering cocoa farmers in the village community Kayuangin Malunda District of Majene. Research type is descriptive and qualitative and quantitative combined with taking samples from the level of stakeholder related to the level of Head of the nodes of lower levels such as village government. Based on the results of research in the village Kayuangin describe that some obstacles were very urgent in light, namely: the level of people's mindsets are still very low given the level of education and knowledge was limited to Junior High School (SMP) alone, the geography has not been possible to distribute the logistics of agriculture so that they become major constraint at present, inadequate extension workers so that they FEA concurrent positions of more than one village.
\end{abstract}

Keywords: Community Development, cocoa farmers

\begin{abstract}
ABSTRAK
Penelitian ini bertujuan untuk mengetahui peran pemerintah daerah dalam pemberdayaan masyarakat petani kakao di Desa Kayuangin Kecamatan Malunda Kabupaten Majene dan mengetahui faktor-faktor yang mempengaruhi peran pemerintah daerah dalam pemberdayaan masyarakat petani kakao di Desa Kayuangin Kecamatan Malunda Kabupaten Majene. Jenis Penelitian adalah Deskriptif dan gabungan Kualitatif dan kuantitatif dengan mengambil sampel mulai dari tingkat Stakeholder yang terkait dari tingkat Kepala Dinas hingga pada simpul-simpul pemerintahan yang lebih rendah seperti pemerintah desa. Berdasarkan hasil penelitian yang ada di Desa Kayuangin mendeskripsikan bahwa beberapa kendala yang sangat urjen yaitu: tingkat pola pikir masyarakat masih sangat rendah mengingat tingkat pendidikan dan pengetahuan hanya sebatas Sekolah Menengah Pertama (SMP) saja, kondisi geografis belum memungkinkan dalam mendistribusikan logistik pertanian sehingga masih menjadi kendala besar saat ini, tenaga penyuluh yang belum memadai sehingga masih ada tenaga penyuluh yang merangkap jabatan lebih dari satu desa.
\end{abstract}

Kata kunci: Pemberdayaan Masyarakat, Petani Kakao 


\section{A. LATAR BELAKANG}

Pemerintah sebagai rangkaian dari lembaga-lembaga memiliki banyak komponen organisasi dengan berbagai kewenangan yang satu sama lain berbeda namun saling berhubungan. Diantara tiga cabang kekuasaan pemerintahan yang ada, kekuasaan eksekutif memiliki paling banyak lembaga-lembaga. Adapun untuk pengelolaan kekuasaan legislatif dan judikatif, lembaga-lembaganya lebih terbatas dibandingkan dengan eksekutif.

Pemerintah merupakan sekumpulan orang-orang yang mengelola kewenangankewenangan dari lembaga-lembaga dimana mereka ditempatkan sebagai personifikasi dari kekuasaan. Jadi, kalau aturan main dan lembaga adalah dua komponen yang bersifat abstrak dan statis dari suatu sistem pemerintahan, maka aparatur birokrasi dan pejabat politik yang duduk di tiga cabang pemerintahan itu adalah komponen yang konkrit, aktif dan dinamis.

Dalam hal ini, pemerintah mempunyai tanggung jawab dalam hal pemberdayaan masyarakat. Unsur utama dari proses pemberdayaan masyarakat adalah pemberian kewenangan dan pengembangan kapasitas masyarakat. Kedua unsur tersebut tidak dapat dipisahkan, oleh karena apabila masyarakat telah memperoleh kewenangan tetapi tidak atau belum mempunyai kapasitas untuk menjalankan kewenangan tersebut maka hasilnya juga tidak optimal. Menurut Soetomo, (2011:88), Masyarakat berada pada posisi marginal disebabkan karena kurang memiliki kedua unsur tadi, kewenangan dan kapasitas. Kondisi tersebut sering juga disebut masyarakat kurang berdaya atau powerless, sehingga tidak mempunyai peluang untuk mengatur masa depannya sendiri. Hal itulah yang dianggap sebagai penyebab utama kondisi kehidupannya tidak sejahtera.

Hal itu sangat sejalan dengan kondisi sosial kemasyarakatan yang ada di daerah Sulawesi Barat yang kaya akan Sumber
Daya Alam khususnya di bidang Pertanian. Kesejahteraan masyarakat Sulawesi Barat dapat diciptakan (created) melalui pengembangan industri berbasis sektor pertanian (agroindustry). Agroindustri adalah kegiatan industri yang mengolah hasil-hasil pertanian sebagai industri hilir yang berlokasi di perdesaan dan secara fungsional dapat meningkatkan posisi tawar petani dalam meraih nilai tambah, Menurut Hapsah dalam Burhanuddin, (2007:95).

$$
\text { Kurangnya koordinasi antar }
$$

pemerintah pusat dan daerah, tidak maksimalnya bimbingan dan supervisi oleh UPTD Pertanian Kecamatan Malunda, program pendidikan dan pelatihan masih belum bisa memberikan pemahaman kepada masyarakat agar menjual kakao terfermentasi demi menambah nilai jual. Hal inilah yang membuat tertarik untuk meneliti tentang peran pemerintah daerah dalam pemberdayaan masyarakat petani kakao di Desa Kayuangin Kecamatan Malunda Kabupaten Majene.

Dengan selesainya penelitian ini, maka diharapkan dapat meningkatkan perhatian pemerintah daerah kepada petani kakao khususnya di Desa Kayuangin, melahirkan regulasi khusus tentang penjualan produksi kakao yang terfermentasi, pelaksanaan pendidikan dan pelatihan serta bimbingan dan supervisi tetap berjalan sebagaimana mestinya mengingat tingginya produksi kakao Sulawesi Barat sebagai penyumbang terbesar di Indonesia dan kedua di Dunia namun tidak relevan dengan kondisi yang akan karena masih banyak petani kakao yang belum sejahtera dan masih berada pada kehidupan yang tidak layak.

\section{B. KERANGKA KONSEP}

Perintah adalah perkataan yang menyuruh melakukan sesuatu. Pemerintah adalah kekuasaan memerintah suatu negara (daerah negara) atau badan tertinggi yang memerintah sesuatu negara (seperti kabinet merupakan suatu pemerintah), sedangkan 
pemerintahan adalah perbuatan (cara, hal, urusan, dan sebagainya) memerintah. Sedangkan, Pemerintah adalah institusi (institution) atau lembaga yang melaksanakan kegiatan pemerintahan (action). Secara sempit, pemerintah adalah eksekutif dan administrasi negara. Pemerintahan sebagai kegiatan (action) adalah segala kegiatan yang terorganisir yang dilakukan oleh pemerintah yang bersumber pada Kedaulatan Negara yang meliputi yurisdiksi teritorial dan yurisdiksi personil, demi tercapainya tujuan daripada Negara.

Sedangkan, pemerintah dalam Negara Kesatuan bermakna yang menentukan wewenang apa saja yang akan diberikan oleh pemerintah pusat tersebut maka pemerintah di daerah tidak dibenarkan untuk mengatur dan mengurusnya.

Finner dalam Pamudji (1986:52) berpendapat bahwa istilah government mempunyai empat arti, yaitu: (1) Menunjukkan kegiatan atau proses memerintah, yaitu melaksanakan kontrol atas pihak lain (The Activity or the process governing); (2) Menunjukkan masalahmasalah (hal ikhwal negara dalam mana kegiatan atau proses diatas dijumpai (states of affairs); (3) Menunjukkan orang-orang (pejabat-pejabat) yang dibebani tugas-tugas untuk memerintah (people charged with the duty governing); (4) Menunjukkan cara metode atau sistem dengan mana suatu masyarakat tertentu diperintah (the manner method or system by which particular society is governed).

Keseluruhan organisasi pemerintah yang menjalankan tugas-tugas negara dalam berbagai unit organisasi pemerintah dibawah departemen dan lembaga non departemen, baik di tingkat pusat maupun di daerah, seperti provinsi, kabupaten, kecamatan bahkan di tingkat kelurahan/desa. Sedangkan pemerintah merupakan sekelompok individu yang mempunyai wewenang tertentu untuk melaksanakan kekuasaan. Sementara itu,
Soewarno dalam buku yang sama mengungkapkan kalau pemerintah adalah badan yang menjalankan tugas-tugas publik pemerintahan dan pembangunan, pemerintah adalah badan eksekutif dan pelaksanaan tugas-tugasnya mendapat pengawasan dari badan legislatif.

Pemerintah daerah (daerah otonom) merupakan suatu bagian, suatu wilayah hukum dari pada negara yang tidak mempunyai kekuasaan (power/authority) yang lain dari pada yang sudah diberikan oleh pemerintah pusat (Negara), dan apabila daerah otonom itu keluar dari batas kewenangan yang telah diberikan mealui peraturan perundang-undangan maka daerah otonom itu dapat dikejar terus oleh pemeritah pusat (Negara) sebagai kekuasaan lebih tinggi, dimana Pemerintah daerah adalah kepala daerah dan dewan perwakilan rakyat daerah, yang selanjutnya disebut daerah otonom adalah kesatuan masyarakat hukum yang mempunyai batas wilayah tertentu yang berhak, berwenang dan berkewajiban mengatur dan mengurus rumah tangganya sendiri dalam ikatan Negara Kesatuan Indonesia sesuai dengan peraturan perundang-undangan.

Peraturan penyelenggaraan pemerintahan tentunya terdapat satu ketentuan dasar atau pedoman dasar, dimana penyelenggaraan pemerintahan daerah telah diatur dan dicantumkan pada pasal 18 Undang-undang Dasar 1945 Amandemen pada tahun 2002, dimana terdapat 7 (tujuh). Negara Kesatuan Republik Indonesia dibagi atas daerahdaerah provinsi dan daerah provinsi itu dibagi atas kabupaten dan kota, yang tiaptiap provinsi, kabupaten, dan kota itu mempunyai pemerintahan daerah, yang diatur dengan Undang-undang. Pemerintah daerah provinsi, daerah kabupaten, dan kota mengatur dan mengurus sendiri urusan pemerintahan menurut asas otonomi dan tugas pembantuan, Pemerintahan daerah Provinsi, daerah kabupaten, dan kota memiliki Dewan 
Perwakilan Rakyat Daerah yang anggotaanggotanya dipilih melalui pemilihan umum, gubernur, Bupati dan Walikota masing-masing sebagai kepala pemerintah daerah Provinsi, Kabupaten dan Kota dipilih secara demokratis, Pemerintahan daerah menjalankan otonmomi seluas-luasnya, kecuali urusan pemerintahan yang oleh undang-undang ditentukan sebagai urusan Pemerintah Pusat, Pemerintah daerah berhak menetapkan peraturan daerah dan peraturan peraturan lain untuk melaksanakan otonomi dan tugas pembantuan, Susunan dan tata cara penyelenggaraan pemerintahan daerah diatur dalam undang-undang (Amandemen UUD 1945 pada tahun 2002).

Untuk kemudian diatur dalam pelaksanaan Undang-Undang Nomor 32 Tahun 2004 tentang Pemerintahan Daerah yang dilaksanakan secara luas, nyata dan bertanggungjawab. Berdasarkan Undangundang Nomor 32 Tahun 2004 tentang Pemerintahan Daerah, dinyatakan bahwa Pemerintah Pusat selanjutnya disebut Pemerintah adalah Presiden Republik Indonesia yang memegang kekuasaan pemerintahan negara Republik Indonesia sebagaimana dimaksud dalam UndangUndang Dasar Negara Republik Indonesia tahun 1945. Sedangkan, Pemerintahan daerah adalah penyelenggaraan urusan pemerintahan oleh pemerintah daerah dan DPRD menurut asas otonomi dan tugas pembantuan dengan prinsip otonomi seluas-luasnya dalam sistem dan prinsip Negara Kesatuan Republik Indonesia sebagaimana dimaksud dalam UndangUndang Dasar Negara Republik Indonesia Tahun 1945.

Secara garis besar Peranan menurut Soerjono dalam Bahtiar (2002:8) adalah merupakan aspek dinamis kedudukan (status). Apabila seseorang melaksanakan hak dan kewajiban sesuai dengan kedudukannya maka ia dikatakan menjalankan suatu peranan. Sedangkan, menurut UU No. 32/2004 pasal 217, dalam menjalankan peran dari pemerintah maka pembinaan atas penyelenggaraan pemerintah daerah dilaksanakan oleh pemerintah yang meliputi: (1) Koordinasi pemerintah antar susunan pemerintahan; (2) Pemberian pedoman dan standar pelaksaan urusan pemerintahan; (3) Pemberian bimbingan, supervisi, dan konsultasi pelaksanaan urusan pemerintahan; (4) Pendidikan dan pelatihan, dan; (5) Perencanaan, penelitian, pengembangan, pemantauan dan evaluasi pelaksanaan urusan pemerintahan.

Peran pemerintah merupakan keperluan mutlak dalam suatu organisasi baik organisasi pemerintah maupun organisasi swasta dan merupakan salah satu fungsi utama yang harus dilaksanakan oleh seorang pemimpin. Kurangnya komunikasi dan koordinasi dalam suatu organisasi. Maka akan terwujud masyarakat berdaya yang memiliki kekuatan atau kemampuan kognisi, psikomotorik, afektif terhadap urusan sosial (akses terhadap dasar-dasar produksi tertentu), politik (kemandirian dalam pengambilan keputusan) dan psikologis untuk membangun kepercayaan diri. Pemberdayaan menekankan bahwa orang seharusnya memperoleh keterampilan, pengetahuan dan kekuasaan yang cukup untuk mempengaruhi kehidupannya dan kehidupan orang lain yang menjadi perhatiannya. Pendapat Parsons dalam Hakim (2010:10).

Pemberdayaan dapat disimpulkan adalah upaya menggalang potensi yang ada di masyarakat secara praktis dan produktif untuk mencapai tujuan dengan pemberian daya dan kekuatan untuk melaksanakan tugas ataupun target yang dicapai.

\section{METODE PENELITIAN}

Waktu penelitian ini dilaksanakan selama dua bulan yang berlokasi di Desa Kayuangin Kecamatan Malunda Kabupaten Majene. Karena daerah tersebut merupakan daerah yang mayoritas petani Kakao dan sangat relevan dengan judul yang akan diteliti dengan menggunakan Jenis 
penelitian yang digunakan pada penelitian ini ialah gabungan kualitatif dan kuantitatif, yang artinya adalah menggambarkan tentang Peran Pemerintah Daerah Dalam Pemberdayaan Masyarakat Petani Kakao Di Desa Kayuangin Kecamatan Malunda Kabupaten Majene. Dan realita empirik dibalik fenomena secara terperinci, mendalam, dan tuntas.

Dengan menggunakan sumber data primer dan Data sekunder untuk memperkuat penemuan dan melengkapi informasi yang telah dikumpulkan melalui wawancara langsung dengan masyarakat yang tergolong sebagai petani kakao. Pemilihan narasumber dalam penelitian ini berdasar purpose sampling, narasumber dilakukan berdasarkan jenis informasi atau pertimbangan yang sudah ada/ditetapkan sebelumnya dengan syarat bahwa masyarakat yang mengetahui tentang kakao dan adanya identifikasi atas kelompok/ orang yang memiliki kekhususan tertentu (terkait jabatan, kepakaran/ expert sampling, dan pengalaman dalam usaha kakao).

Dengan menggunakan tehknik pengumpulan data melalui observasi, dokumentasi dan penyebaran kuesioner kepada responden guna melengkapi hasil penelitian serta dengan metode deskriptif gabungan kualitatif dan kuantitatif yang merupakan suatu teknik yang menggambarkan dan menginterprestasikan arti data-data yang telah terkumpul dengan memberikan perhatian dan merekam sebanyak mungkin aspek situasi yang diteliti saat itu, sehingga memperoleh gambaran secara umum dan menyeluruh tentang keadaan yang sebenarnya.

Tujuan deskriptif ini adalah membuat deskripsi, gambaran, atau lukisan secara sistematis, faktual dan terpercaya, serta akurat terhadap fakta-fakta, sifat-sifat, serta hubungan antara fenomena yang diselidiki.

\section{HASIL DAN PEMBAHASAN}

Peran Pemerintah Daerah Dalam Pemberdayaan Masyarakat Petani Kakao di Desa Kayuangin Kecamatan Malunda Kabupaten Majene menjadi pilihan utama yang dikembangkan di Kabupaten Majene karena komoditas ini memberikan kontribusi yang besar terhadap pendapatan masyarakat dan banyak menyerap tenaga kerja di Kabupaten Majene. Pada tahun 2010, sektor pertanian adalah penyumbang terbesar dalam Produk Domestik Regional Bruto (PDRB) Kab. Majene yakni mencapai 51 persen dimana 39 persen dari PDRB sektor pertanian berasal dari subsektor perkebunan. Terdapat tiga kecamatan yang menjadi sentra produksi kakao di Majene yakni kecamatan Tammerodo, Ulumanda dan Malunda dengan total produksi kakao di tiga kecamatan tersebut mencapai 91 persen dari total produksi kakao di Kabupaten Majene. Sementara Kecamatan Malunda merupakan kecamatan dengan produksivitas dan jumlah petani kakao tertinggi. Produktivitasnya mencapai 940 $\mathrm{Kg} / \mathrm{Ha}$ dengan jumlah petani sebanyak $2.225 \mathrm{KK}$.

Saat ini pemerintah Kabupaten Majene mengembangkan mata rantai dalam pengembangan usaha kakao di Kabupaten majene sehubungan dengan peran pemerintah daerah terhadap pemberdayaan masyarakat petani kakao di desa Kayuangin kecamatan Malunda Kabupaten Majene. Rantai nilai pertama adalah rantai nilai penyedia input atau sarana produksi (Saprodi), kemudian rantai nilai budidaya kakao itu sendiri, rantai nilai pengolahan, dan yang paling akhir rantai nilai perdagangan.

Penyediaan Sarana Produksi (SAPRODI) untuk perawatan atau pemeliharaan berupa gunting pangkas, pupuk pestisida. Sementara saprodi untuk pemanenan berupa gunting potong. Adapun stakeholder yang berperan pada rantai Sarana produksi (Saprodi) adalah pedagang Saprodi, Unit Pengolah hasil (UPH), pemerintah Provinsi dan pemerintah 
daerah. Stakeholder yang paling berperan dalam rantai Saprodi adalah pedagang saprodi baik eceran maupun grosir dan UPH. Melaksanakan Budidaya/Usaha Perkebunan untuk kegiatan-kegiatan on farm antara lain perawatan kebun seperti penyemprotan pestisida, pemangkasan, pemupukan sampai pada pemanenan kakao. Stakeholder lain di dalam rantai budidaya ini adalah Pemerintah Daerah (PEMDA), tenaga pendamping dan juga kelompok tani.

Terdapat beberapa aspek dalam rantai nilai budidaya ini, yaitu:

a) Produksi;

b) Kelembagaan;

c) Sumber Daya Manusia.

Distribusi dan Pemasaran yang merupakan salah satu faktor yang menentukan adalah tingkat harga dan stabilitas harga. Semakin tinggi harga jual biji kakao maka petani akan termotivasi untuk meningkatkan produksinya.

Ada tiga saluran utama pemasaran kakao di Kabupaten Majene :

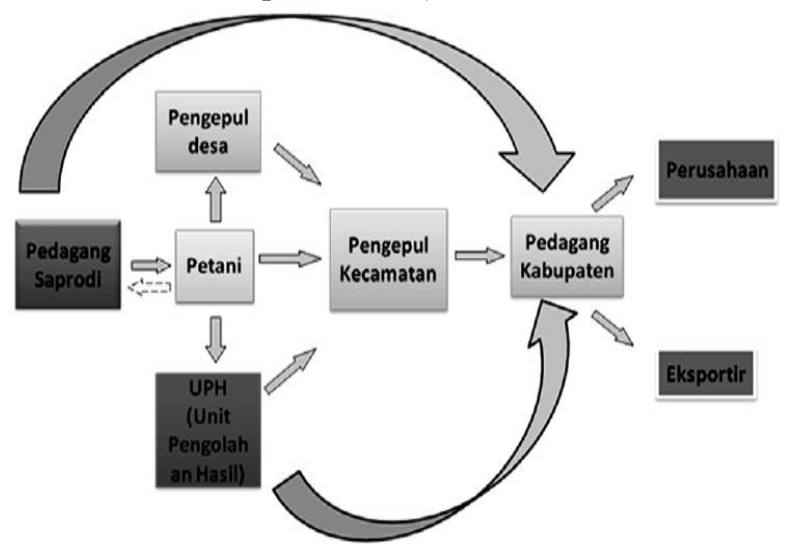

Sumber: Hasil Penelusuran Lapangan

Sehubungan dengan program dari pemerintah tersebut, maka saat ini pemerintah desa telah melaksanakan kegiatan berdasarkan regulasi dan bimbingan teknis dari pemerintah daerah melalui dinas perkebunan dan kehutanan kabupaten Majene. Implementasi dari peran pemerintah daerah dalam pemberdayaan masyarakat petani kakao di desa Kayuangin kecamatan Malunda Kabupaten Majene telah melaksanakan Koordinasi, dimana Pemerintah desa kayuangin telah melaksanakan kegiatan terpola dan terorganisir berdasarkan bimbingan dari pemerintah daerah melalui dinas perkebunan dan kehutanan kabupaten Majene berdasarkan peraturan daerah No. 4 tahung 2011 tentang pembentukan organisasi dan tata kerja lembaga teknis daerah pemerintah kabupaten majene sebagai hasil revisi peraturan daerah No. 14 tahun 2008.

Di sisi lain, Bimbingan dan Supervisi telah berupaya meningkatkan produksi kakao dengan orientasi dan terfokus kepada mutu dan kualitas kakao yang dihasilkan, rendahnya nilai jual kakao Indonesia di pasar internasional diakibatkan karena kurangnya terfermentasi kakao Indonesia sehingga hanya berkisar 10 persen kakao Indonesia yang dicampurkan dalam bahan makanan.

Hal ini terbukti dengan tingginya produksi kakao Indonesia namun belum mampu menekan angka nilai jual yang tinggi pula diakibatkan karena mempunyai supervisor dari UPTD Pertanian Kecamatan Malunda namun masih merangkap terhadap desa-desa lain sehingga belum mampu menjangkau dalam satu minggu untuk melaksanakan pendampingan terhadap petani kakao di desa Kayuangin yang secara spesifik masyarakat setempat masih melakukan secara mandiri dengan tingkat pengetahuan yang masih rendah. Selain itu, kendala utama yang ditemui di lapangan bahwa tenaga pendamping yang ada sekarang masih ada yang berlatar belakang keilmuan yang berbeda sehingga petani masih kurang mendapat solusi yang jelas ketika mendapat kendala di lapangan.

Konsultasi merupakan sesuatu hal yang berkaitan satu sama lain serta merupakan turunan yang satu sama lain menjadi bagian yang tak terpisahkan namun terkadang perencanaan (Planning) berbeda dan berbanding terbalik dengan implementasi di lapangan karena disebabkan berbagai macam faktor eksternal yang mampu mempengaruhi 
kondisi lapangan maka seperti itulah yang terjadi di Desa Kayuangin terhadap implementasi program yang menjadi jawaban terhadap pemberdayaan masyarakat petani kakao di Desa Kayuangin kecamatan Malunda Kabupaten Majene. Melalui kendala dilapangan yang dimungkinkan akan terjadi maka pemerintah daerah melakukan susunan dan standar operasional dalam perangkuman aspirasi di setiap lini dengan mengedepankan Quick Respon dari masingmasing kelompok tani. Saat ini terdapat 13 Kelompok tani di Desa Kayuangin, dimana empat diantaranya telah menjadi Gabungan Kelompok Tani (Gapoktan) yang masingmasing telah menjadi kelompok andalan binaan dari Pemerintah daerah dan secara langsung menjadi pembimbing bagi kelompok yang belum terdaftar sebagai Gapoktan.

Pendidikan dan Pelatihan masih terfokus pengembangan bagi pemerintah daerah yang notabenenya dan mayoritas petani Majene masih mempunyai tingkat pendidikan masih rendah yang secara khusus kelompok tani yang ada di Desa Kayuangin masih mempunyai tingkat pendidikan yang setara dengan sekolah dasar (SD) dan sekolah menengah pertama (SMP). Adapun langkah real yang saat ini dilakukan oleh pemerintah daerah yaitu sebagai berikut: (1) Peningkatan Sumber daya Manusia; dan (2) Penguatan Kelembagaan.

Upaya dari pemerintah kabupaten Majene sebagai daerah kakao nasional menjadi bagian yang tak terpisahkan dari berbagai kebijakan yang dituangkan dalam peraturan daerah sebagai hasil yang diharapkan menjadi solusi bagi peningkatan produksi yang akan berdampak terhadap kesejahteraan petani kaitannya dengan produksi melimpah. Dari berbagai hasil analisis tahun 2013 baik pemerintah daerah pemerintah desa menunjukkan bahwa kendala besar yang dihadapi oleh pemerintah sehubungan dengan peran pemerintah dalam pemberdayaan petani kakao yaitu sebagai berikut:

a) Sumber Daya Manusia;

b) Infrastruktur;

c) Sarana dan Prasarana

Faktor-faktor yang mempengaruhi peran pemerintah daerah dalam pemberdayaan masyarakat petani kakao di Desa kayuangin Kecamatan Malunda Kabupaten Majene. Faktor Internal diantaranya kurangnya sarana produksi, kurangnya penguatan kelembagaan, rendahnya pengetahuan petani. Sedangkan, Faktor Eksternal termasuk diantaranya kondisi geografis yang berada di perbukitan dan dataran rendah, Tenaga Penyuluh di Kecamatan Malunda masih sangat sedikit.

Pemerintah mulai menyadari bahwa peningkatan kesejahteraan rakyat merupakan salah satu agenda tahunan yang harus mendapatkan perhatian utama, untuk itu sekarang pemerintah berusaha melakukannya melalui Program Nasional Pemberdayaan Masyarakat-Mandiri (PNPM Mandiri). Dan melalui Program Kredit Usaha Rakyat (KUR). Hal ini dilakukan untuk meningkatkan daya beli masyarakat, dan mendorong produktivitas masyarakat dalam penyediaan barang dan jasa. Sehingga jika diteliti lebih jauh program ini tidak saja berfungsi untuk menanggulangi kemiskinan, tetapi juga sebagai stimulus untuk menggenjot pertumbuhan ekonomi.

Sejalan dengan program Pemerintah Pusat, Pemerintah di berbagai daerah juga telah berusaha membuat berbagai program yang bertujuan untuk meningkatkan pendapatan bagi rumah tangga miskin dan membuka lapangan kerja pada sektor informal salah satunya melalui pemberdayaan masyarakat di berbagai bidang yang bertujuan meningkatkan kesejahteraan masyarakat. Oleh karena itu diharapkan dengan adanya kebijakan pemerintah yang lebih mendukung peningkatan potensi sumber daya alam dan menyeimbangkan sumber daya manusia pada daerah tersebut.. 
Peningkatan Lapangan Kerja dan Pembangunan ekonomi merupakan proses perubahan dari suatu tipe perekonomian menjadi tipe lain yang lebih maju (Hirschman). Sedangkan menurut Meier dan Baldwin, pembangunan ekonomi adalah suatu proses, dengan proses dimana pendapatan nasional real suatu perekonomian bertambah selama suatu periode waktu yang panjang. Berdasarkan pengertian dari kedua tokoh tersebut, pembangunan dikatakan sebagai sebuah proses karena pembangunan bukanlah suatu kegiatan yang momentum atau perbuatan yang selesai hanya dalam satu kali dalam suatu saat, melainkan pembangunan merupakan suatu kegiatan yang terus-menerus.

Pembangunan nasional dilaksanakan dalam rangka pembangunan ekonomi, manusia, sosial budaya, dan politik di Indonesia, untuk mewujudkan masyarakat yang sejahtera, adil, dan makmur. Dalam melaksanakan pembangunan nasional, perluasan lapangan kerja dan peningkatan kualitas tenaga kerja mempunyai peranan dan kedudukan yang sangat penting sebagai pelaku dan tujuan pembangunan. Upaya perluasan lapangan kerja di dalam suatu negara dilakukan karena meningkatnya penawaran terhadap jumlah tenaga kerja sehingga mereka dapat disalurkan ke lapangan-lapangan yang tersedia agar tenaga kerja yang berlebihan tersebut semakin produktif. Keterkaitan jumlah tenaga kerja yang berlebihan tersebut, disebabkan adanya pertumbuhan penduduk yang cepat seperti yang dialami di negaranegara berkembang.

Untuk itu diharapkan dengan adanya peran pemerintah daerah ini dapat menciptakan lapangan kerja bagi masyarakat desa setempat sehingga tidak ada lagi pengangguran dan masyarakat dapat hidup dengan sejahtera. Melalui kreativitasnya masyarakat dapat mengembangkan kemampuan dirinya untuk menciptakan lapangan kerja yang dapat menunjang kehidupannya.

\section{E. KESIMPULAN}

Peran pemerintah daerah dalam pemberdayaan masyarakat petani kakao di Desa Kayuangin Kecamatan Malunda Kabupaten Majene belum berjalan baik. Hal ini dapat terlihat dari tahap pembuatan peraturan daerah (PERDA) sampai dengan terealisasinya kegiatan lapangan. Akan tetapi pencapaian tujuan Pemberdayan masyarakat petani belum memuaskan. Hal ini dapat dilihat dari pencapaian tujuan pemberdayaan masyarakat yaitu diharapkan mampu mengangkat tingkat kesejahteraan petani, penguatan kelembagaan, meningkatnya kemampuan masyarakat agar mampu lebih mandiri.

Peran Pemerintah Daerah melalui Dinas Perkebunan dan Kehutanan Kabupaten Majene telah merealisasikan berbagai program sebagai bentuk upaya pemerintah dalam peningkatan kesejahteraan sosial namun kebijakannya yang sudah dilaksanakan namun belum sepenuhnya berjalan dengan baik dan masih belum maksimal, artinya bahwa pemerintah hanya mendapati laporan tanpa peninjauan langsung ke lapangan dengan masih maksimalnya bimbingan dan pelatihan, pendidikan dan pelatihan yang belum mampu merubah pemahaman masyarakat mengenai budidaya kakao yang baik, serta pemantauan dan evaluasi yang tidak ada tindak lanjutnya.

Faktor-faktor yang mempengaruhi peran pemerintah Daerah dalam pemberdayaan masyarakat petani kakao di Desa Kayuangin Kecamatan Malunda Kabupaten Majene karena Petani belum merasakan manfaat secara maksimal dari sarana produksi yang telah dibagikan oleh pemerintah karena mengingat kondisi geografis yang ada sehingga proses pendistribusian sangat lambat dan membutuhkan biaya lebih bagi masyarakat diperbukitan dibanding dengan yang ada di pesisir pantai, 
Petani masih kurang kesadaran agar menjual biji kakao yang sudah memiliki standar kekeringan tertentu. Masih banyak petani yang menjual biji kakao dengan pengeringan asalan (tanpa fermentasi) dan ditambah lagi kelembagaan yang ada seperti Kelompok Tani atau Gabungan Kelompok Tani belum dapat menguatkan posisi tawar petani di dalam pasar karena kelembagaan yang ada baru pada tingkat inisiasi saja. Gapoktan pun tidak berfungsi sebagaimana mestinya namun yang lebih menonjol adalah petani yang sering menjual langsung ke tengkulak.

Rendahnya pengetahuan petani dengan melihat latar belakang pendidikan yang hanya pada tingkat Sekolah Dasar (SD) dan Sekolah Menengah Pertama (SMP) menyulitkan dalam memberikan pemahaman kepada masyarakat mengenai budidaya kakao yang baik serta diperparah dengan Tenaga Penyuluh yang bukan dari disiplin ilmu Pertanian menjadi penghambat penyelesaian teknis di lapangan dan daerah perbukitan merupakan kendala besar terutama pada musim hujan Karen selain menghambat proses distribusi logistik, bantuan dan proses pemasaran juga memerlukan biaya tambahan dalam hal aksesnya karena memerlukan kendaraan khusus.

Dengan demikian Pemerintah daerah seyogyanya memberikan perlakuan khusus kepada petani yang berada di perbukitan dibanding dengan petani yang ada di wilayah pesisir dengan pertimbangan kondisi geografis yang menjadi kendala dalam proses pendistribusian bantuan pertanian, Para penyuluh yang ada di lapangan sebaiknya tidak merangkap desa dalam hal pembinaan karena mengingat akses yang sulit sehingga sulit untuk dijangkau. Sementara itu, kendala besar bahwa masih terdapat pendamping lapangan yang bukan pada disiplin ilmunya sehingga terjadi kerancuan dalam pembinaan dan tidak perhatian khusus.
Kurangnya kesadaran masyarakat dalam perhatiannya terhadap penguatan kelembagan sehingga mendapatkan kemudahan akses dalam memasuki pasar yang berimplikasi kepada peningkatan nilai jual kakao produksi petani yang tentunya dapat menentukan sendiri nilai jual dan mudah dalam mengadakan kerjasama dengan perusahaaan, Kendala besar dari kakao produksi Indonesia masih mempunyai mutu atau kualitas yang masih rendah dengan terbukti bahwa dalam pencampuran bahan makanan untuk produksi, kakao Indonesia digunakan hanya kisaran antara 10 persen. Hal ini menjadi perhatian khusus agar kiranya pemerintah dan masyarakat harus lebih fokus dan menaruh perhatian lebih kepada kesadaran petani dalam menghasilkan kakao terfermentasi, Para penyuluh harus lebih terfokus keapada peningkatan pemahaman petani dengan melakukan pendampingan secara intensif, bukan dengan hanya menggugurkan kewajiban namun tidak ada manfaat yang didapatkan dari tujuan program tersebut.

\section{DAFTAR PUSTAKA}

Bahtiar, A. M. 2011. Peranan Pemerintah Kecamatan dalam Pelaksanaan Pembangunan Partisipatif (Pembangunan Irigasi) di Kecamatan Masamba Kab. Luwu Utara. Unismuh Makassar.

Burhanuddin, T. 2007. Menata Masa Depan Sulawesi Barat. Makassar: PT. Satria Media.

Hakim, Lukman. 2010. Pemberdayaan Masyarakat Sketsa Teori dan Pendekatan. Makassar: CV. Berkah Utami.

Pamudji, S. S. 2012. Administrasi Pembangunan: Konsep, Dimensi dan Strateginya. Jakarta: Bumi aksara.

Soetomo. 2011. Pemberdayaan Masyarakat. Yogyakarta: Pustaka Pelajar. 
Vol. IV No. 1 April 2014

UU No. 32 Tahun 2004 Tentang Pemerintahan Derah. Pustaka Pelajar. Yogyakarta.

Data Statistik Perkebunan Tahun 2012. Aksara Lontara. Mamuju. 